\title{
Influence of Class II Elastics on Centric Relation and Centric Occlusion Discrepancy after Orthodontic Treatment
}

\author{
Influencia de los Elásticos de Clase II sobre la Discrepancia de Relación \\ Céntrica para la Oclusión Céntrica Después del Tratamiento Ortodóncico
}

\author{
Érico Marcel Gomes de Carvalho1; Maria Rita Esteves"; Martinho Campolina Rebello Horta1; \\ Giordani Santos Silveira' \& Paulo Isaías Seraidarian¹
}

DE CARVALHO, É. M. G.; ESTEVES, M. R.; HORTA, M. C. R.; SILVEIRA, G. S. \& SERAIDARIAN, P. I. Influence of class II elastics on centric relation and centric occlusion discrepancy after orthodontic treatment. Int. J. Odontostomat., 11(4):487493, 2017.

\begin{abstract}
The objective of this study was to verify the influence of the use of Class II intermaxillary elastics on centric relation $(\mathrm{CR})$ to centric occlusion $(\mathrm{CO})$ occlusal discrepancy. A total of 30 patients had been at the contention stage for at least three months were divided in two groups: G1 - 15 had been submitted to intramaxillary orthodontic mechanics only, and G2 - 15 had used Class II intermaxillary elastics. Distances of horizontal and vertical overlap and the distance or coincidence of the mandibular dental midline in relation to the maxillary midline were measured in CR and CO positions. Intergroup comparisons were performed using the Mann-Whitney test. No statistically significant differences $(P>0.05)$ were found between G1 and G2. Both in the horizontal and vertical directions, these discrepancies were smaller than or equal to $1 \mathrm{~mm}$ in $96.66 \%$ of the patients. In the transverse plane, there was no discrepancy in $63.33 \%$ of the patients, and in 33.33 $\%$ these discrepancies were equal to $0.5 \mathrm{~mm}$. The use of Class II elastic didn't be capable of increasing the occlusal discrepancies between $\mathrm{CR}$ and $\mathrm{CO}$.
\end{abstract}

KEY WORDS: malocclusion, orthodontics, dental occlusion, jaw relation records.

\section{INTRODUCTION}

For more than a century there have been frequent controversial debates about subjects related to dental occlusion. Theories about occlusion have been found in the literature, generally based on convictions, many of which have not been scientifically proved (Türp et al. 2008). In addition to various concepts, there have been changes in the definition of terms about occlusal principles (Aubrey, 1994; Klar et al., 2003; Türp et al.).

In orthodontics, the importance of concluding a treatment with regard to a certain condylar position and occlusal patterns, has also been extensively discussed (Kulbersh et al., 2003). There is a group that defends a broader interpretation of occlusion, in which the temporomandibular joint, neuromuscular system and function must be considered (Roth, 1995; Monnerat \& Mucha, 2000; Olsson \& Lindqvist, 2002; Cordray, 2006; Dawson, 2006; Oliveira et al., 2007; Okesson, 2012).
Therefore, the coincidence between centric relation (CR) and centric occlusion (CO) is of fundamental importance (Roth, 1995; Monnerat \& Mucha; Olsson \& Lindqvist; Cordray; Dawson; Oliveira et al.; Okesson). On the other hand, there are clinicians who do not consider the relevance of the condylar position. The diagnosis of malocclusion is fundamentally based on inspection of models geared and supported by the hands (Kulbersh et al.), with less concern about the dynamics of occlusion (Clark \& Evans, 1998; Clark \& Evans, 2001). Some of these also do not defend the coincidence between $\mathrm{CR}$ and $\mathrm{CO}$, because it has not been clearly established (Rinchuse \& Kandasamy, 2006).

However, although there is no universal unanimity about the characteristics of ideal occlusion (Milosevic \& Samuels, 1998), certain types of dental contacts are harmful to the stomatognathic system,

${ }^{1}$ Department of Dentistry, Pontifical Catholic University of Minas Gerais, Belo Horizonte/MG, Brazil. 
both to the masticatory muscles and the temporomandibular joints, such as: balancing side contacts, unilateral contacts in the retracted position, and large discrepancies between $\mathrm{CR}$ and $\mathrm{CO}$ (Clark \& Evans, 1998; Clark \& Evans, 2001; Hidaka et al. 2002).

Since sagittal Class II elastics, intermaxillary orthodontic accessories, can position the mandibular arch and mandible anteriorly (Cabrera et al., 2003), one infers that they can also displace the condyles from their fossae, since these form part of the mandible. Could sagittal Class II elastics, therefore, increase the discrepancies between the CR and CO positions?

The aim of this study was to verify the influence on the result of orthodontic treatment, with and without the use of Class II elastics, with regard to CR to CO occlusal discrepancy.

\section{MATERIAL AND METHOD}

To make this study feasible, a research project was approved by the Research Ethics Committee of the University (document number 0012.0.213.000-09). For the study, we invited individuals who were undergoing orthodontic treatment at a private clinic with two specialists with at least 8 years of experience. The conclusion of treatment was based on criteria established for a satisfactory morphological or static occlusion in accordance with Andrews' six keys (Andrews, 1972), and on visual inspection of the functional aspects of a mutually protected occlusion (Roth, 1991).

The inclusion criteria were as follows: individuals, irrespective of sex, who were undergoing orthodontic treatment with pre-adjusted edgewise brackets; those whose orthodontic treatment had been concluded at least three months earlier; and those who were completely dentate, except for third molars.

Exclusion criteria was applied to individuals with previous orthognathic surgery; those who had lost teeth; those with anomalies of tooth shape and/or size; and those with signs and symptoms of temporomandibular disorders (TMD).

Thus, 30 patients were selected, 11 men and 19 women. The mean age of these patients was 19 years and 9 months, ranging between 12 years 9 months and 41 years and 3 months.
Among the selected patients, 15 had prior intramaxillary orthodontic mechanics only, because they had Angle's Class I malocclusion. The other 15 patients, who initially had Angle's Class II malocclusion, had received intermaxillary mechanics, specifically with sagittal Class II elastics for a minimum period of 6 months.

Lucia's jig was used with the purpose of standardizing the record of the CR position (Lucia, 1973; Clark \& Evans, 1998). By bilateral manipulation of the mandible (Dawson) and by means of carbon articulating film $12 \mu$, dental contact was recorded on the jig and the marking of first dental contacted, denominated the retracted contact position, was considered the CR position (Fig. 1).

Having concluded this stage, the jig was removed and maxillomandibular relation in $\mathrm{CR}$ was checked again. In this position, by means of a millimetric ruler, with proximity of measurement of $0.5 \mathrm{~mm}$, the distances of horizontal overlap, vertical overlap and the distance or coincidence of the mandibular dental midline in relation to the maxillary midline were measured (Fig. 2) independently, by two professionals.

The horizontal overlap was measured from the vestibular surface of the mandibular left central incisor to the vestibular surface of the maxillary left central incisor, using a millimetric ruler in juxtaposition to the mandibular incisor surface and parallel to the occlusal plane. Vertical overlap was measured from the incisal edge of the maxillary left central incisor to the incisal edge of the mandibular left central incisor, by making a mark on the vestibular surface of the mandibular incisor with a graphite $0.5 \mathrm{~mm}$ pencil, of the projection of the maxillary incisor edge. Finally, horizontal distance between maxillary and mandibular midlines was measured. After this was done the individuals were asked to clench their teeth as intensely as possible in order to determine the CO position. In the same way, the measurements mentioned above were obtained, in order to determine the differences between them in the antero-posterior, vertical and lateral directions.

The Mann-Whitney test was used to compare the discrepancies of $\mathrm{CR}$ to $\mathrm{CO}$, as it concerned the comparison between two non-paired groups, with a cardinal variable and without normal distribution, according to the D'Agostino test. The Wilcoxon test was used to verify the inter-examiner calibration, as it also concerned a cardinal variable without normal distribution of paired groups. 
DE CARVALHO, É. M. G.; ESTEVES, M. R.; HORTA, M. C. R.; SILVEIRA, G. S. \& SERAIDARIAN, P. I. Influence of class II elastics on centric relation and centric occlusion discrepancy after orthodontic treatment. Int. J. Odontostomat., 11(4):487-493, 2017.
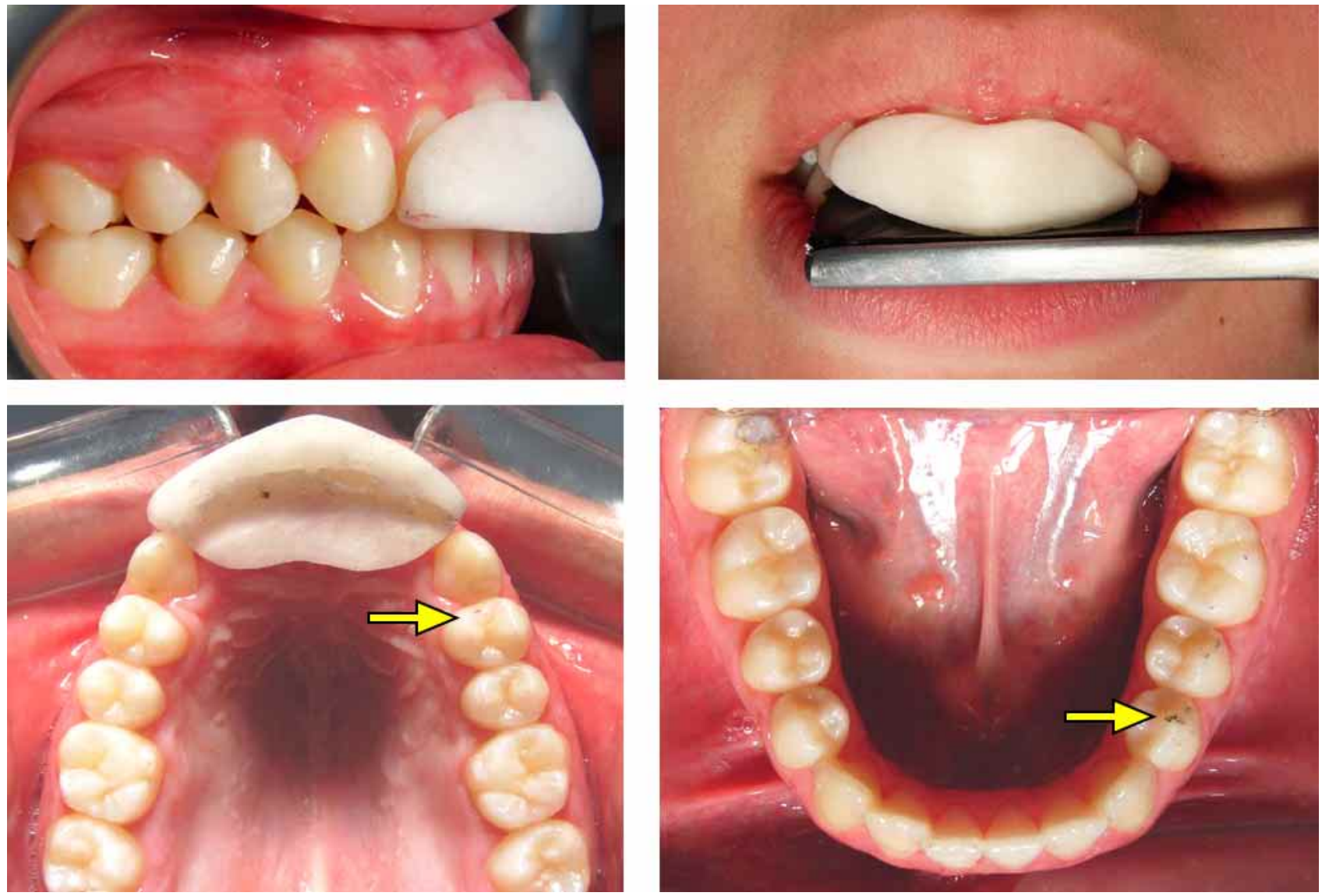

Fig. 1. Marking the first point of contact on the Jig and on the tooth simultaneously, during closure in CR.
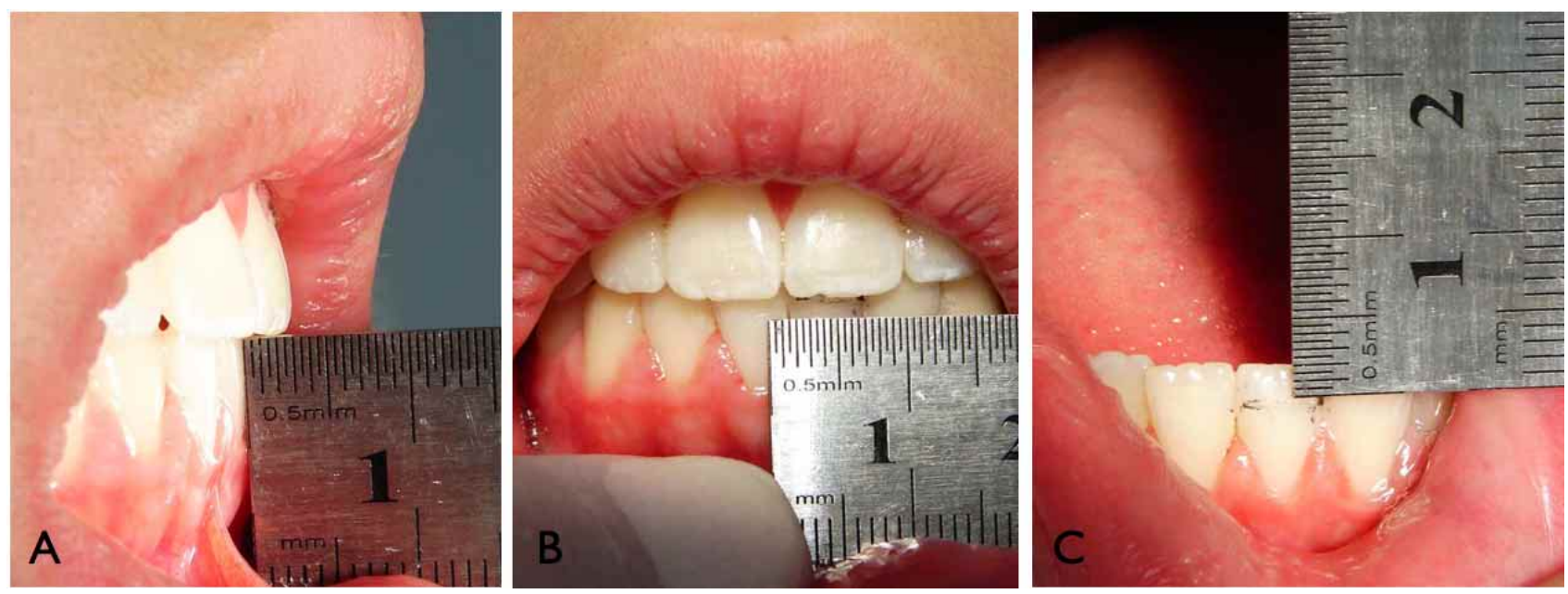

Fig. 2. Obtaining the discrepancies in the horizontal $(A)$, transverse $(B)$ and vertical directions $(C)$.

\section{RESULTS}

No statistically significant differences were found between the two studied groups; that is to say, the group of patients who received intramaxillary orthodontic mechanics only (Group 1), and the group of patients who used sagittal Class II elastics (Group 2). The measurements obtained by the two examiners were 
analyzed by the Wilcoxon statistical test, which showed inter-examiner calibration.

The measurements obtained were separated by group and by spatial dimension (Table I). The values in the column on the left belong to Group 2, and those in the column on the right belong to Group 1, being disposed in the following order: discrepancy in the horizontal, vertical and transverse directions.

With regard to the magnitude of the discrepancies found in this study the following data were obtained:

\section{A) Horizontal direction}

Absence of discrepancy in 5 patients $(16.66 \%)$;

Discrepancy of $0.5 \mathrm{~mm}$ present in 18 patients (60\%);

Discrepancy of $1.0 \mathrm{~mm}$ present in 6 patients $(20 \%)$;

Discrepancy of $1.5 \mathrm{~mm}$ present in 1 patient (3.33\%).

\section{B) Vertical Direction}

Absence of discrepancy in 2 patients $(6.66 \%)$;

Discrepancy of $0.5 \mathrm{~mm}$ present in 16 patients $(53.33 \%)$;

Discrepancy of $1.0 \mathrm{~mm}$ present in 11 patients $(36.66 \%)$;

Discrepancy of $1.5 \mathrm{~mm}$ present in 1 patient $(3.33 \%)$.

\section{C) Transverse Direction}

Absence of discrepancy in 19 patients (63.33\%);

Discrepancy of $0.5 \mathrm{~mm}$ present in 10 patients (33.33 \%);

Discrepancy of $1.0 \mathrm{~mm}$ present in 0 patients;

Discrepancy of $1.5 \mathrm{~mm}$ present in 1 patient (3.33\%).

The Mann-Whitey test was used to compare the measurements between the two groups in the horizontal, vertical, and transverse directions, and the results are shown in Tables II, III and IV, respectively.
Table II. Comparison of horizontal discrepancies between the two groups.

\begin{tabular}{lcc}
\hline \multicolumn{1}{c}{ Results } & Sample 1 & Sample 2 \\
\hline Sample size & 15 & 15 \\
Sum of points (Ri) & 270.0 & 195.0 \\
Median = & 0.50 & 0.50 \\
$\mathrm{U}=$ & 75 & \\
$\mathrm{Z}(\mathrm{U})$ & 1.5554 & \\
$\mathrm{p}-$ value (unilateral) & $0.0599^{*}$ & \\
p - value (bilateral) & $0.1198^{*}$ &
\end{tabular}

* NS: Not significant (Level of significance: $p<0.05$ ).

Table III. Comparison of vertical discrepancies between the two groups.

\begin{tabular}{lcc}
\hline \multicolumn{1}{c}{ Results } & Sample 1 & Sample 2 \\
\hline Sample size & 15 & 15 \\
Sum of points $(\mathrm{Ri})$ & 270.0 & 195.0 \\
Median = & 0.50 & 0.50 \\
$\mathrm{U}=$ & 75 & \\
$\mathrm{Z}(\mathrm{U})$ & 1.5554 & \\
$\mathrm{p}$ - value (unilateral) & $0.0599^{*}$ & \\
$\mathrm{p}$ - value (bilateral) & $0.1198^{*}$ & \\
\hline * NS: Not significant (Level of significance: $p<0.05)$. &
\end{tabular}

Table IV. Comparison of transverse discrepancies between the two groups.

\begin{tabular}{lcc}
\hline Results & Sample 1 & Sample 2 \\
\hline Sample size & 15 & 15 \\
Sum of points (Ri) & 222.5 & 242.5 \\
Median = & 0.00 & 0.00 \\
$\mathrm{U}=$ & 102.50 & \\
$\mathrm{Z}(\mathrm{U})$ & 0.4148 & \\
$\mathrm{p}$ - value (unilateral) & $0.3392^{*}$ & \\
$\mathrm{p}$ - value (bilateral) & $0.6783^{*}$ & \\
\hline
\end{tabular}

${ }^{*} N S$ : Not significant (Level of significance: $p<0.05$ ).

Table I. Measurements of RC-OC discrepancies $(\mathrm{mm})$, per group and per spatial dimension

\begin{tabular}{cccccc}
\hline HOR-G2 & HOR-G1 & VERT-G2 & VERT-G1 & TRAN-G2 & TRAN-G1 \\
\hline 0.5 & 0.5 & 1 & 1 & 0 & 0 \\
0.5 & 0.5 & 0.5 & 0.5 & 0 & 0.5 \\
1.5 & 0.5 & 1 & 0.5 & 0.5 & 0.5 \\
0.5 & 0.5 & 0.5 & 1 & 0 & 1.5 \\
1 & 0.5 & 1 & 0.5 & 0.5 & 0 \\
0 & 0 & 0.5 & 1 & 0 & 0.5 \\
0.5 & 0 & 0.5 & 0 & 0 & 0 \\
0 & 0.5 & 0 & 0.5 & 0 & 0 \\
0.5 & 1 & 0.5 & 1.5 & 0 & 0 \\
0.5 & 0.5 & 1 & 1 & 0.5 & 0.5 \\
1 & 0.5 & 1 & 0.5 & 0 & 0 \\
1 & 0.5 & 1 & 0.5 & 0 & 0 \\
1 & 0.5 & 0.5 & 0.5 & 0 & 0 \\
0.5 & 0 & 0.5 & 0.5 & 0.5 & 0.5 \\
1 & 0.5 & 1 & 0.5 & 0.5 & 0 \\
\hline
\end{tabular}

HOR=horizontal; VERT=vertical; TRAN=transverse G1=group 1; G2=group 2. 


\section{DISCUSSION}

The discrepancy between $\mathrm{CR}$ and CO has been the subject of discussions among innumerable authors (Klar et al.). There are those that preach that this discrepancy should be null (Oliveira et al.), while others argue that it is possible for this discrepancy to exist up to the extent of $3 \mathrm{~mm}$ (Ash \& Ramfjord, 1995). Although there is still no consensus about these values, the search for better types of static and dynamic occlusion continues to be of concern to dentists who seek excellence in their work, a search that has been going on for over a century (Rinchuse \& Kandasamy).

Various authors (Aubrey; Ash \& Ramfjord; Monnerat \& Mucha; Olsson \& Lindqvist; Klar et al.; Cordray; Dawson; Oliveira et al.; Okesson) consider control of the values of discrepancy between CR and $\mathrm{CO}$ necessary and useful in techniques that involve the re-establishment of a functional occlusion, whether in prosthetic rehabilitation or in orthodontics. Therefore, in orthodontic conclusion, the certain condylar position and adequate occlusal parameters are important.

If on the one hand professionals guided by gnathology support the view that the coincidence between $\mathrm{CR}$ and $\mathrm{CO}$ is fundamental for successful treatment, others (Hwang \& Behrents, 1996; Clark \& Evans, 1998; Clark \& Evans, 2001; Ellis \& Benson, 2003; Rinchuse \& Kandasamy) argue that this need has not be clearly established or measured. For these professionals, the goal of orthodontic treatment includes obtainment of the best occlusal scheme, within acceptable aesthetics and stable results (Clark \& Evans, 2001; Kulbersh et al.).

The hypothesis that the use of sagittal Class II elastic would, in theory, be capable of increasing the discrepancies between $\mathrm{CR}$ and $\mathrm{CO}$, was not proved in this research, which has also been studied previously (Zhou et al., 2010). If on the one hand the component of anterior force of the sagittal Class II elastic is capable of protracting the mandible in the anterior direction, it is also capable of bringing the entire mandibular arch forward, by means of the orthodontic effect or dental compensation, in addition to promoting the inclination of the mandibular incisors in the vestibular direction (Cabrera et al.).

Another point is the fact that there is also the component of vertical force in the mandible, which causes an extrusive force on the mandibular molars; a force that increases considerably, as the patient makes mouth opening movements. It could cause premature contacts on these teeth, with consequent increase in the discrepancy between CR and CO.

Some authors allege that the observation of discrepancies at occlusal level does not precisely reflect the real modification that occurs with regard to the condylar axis (Hidaka et al.; Cordray). If the treatment goal includes the ideal position of the condyle in the articular fossa, it is essential to evaluate it by the condylar position indicator (Klar et al.). This instrument is precise, reproducible and reliable (Cordray). In the present study, the option was to take the measurements directly in the patients, according to the methodology used by other authors (Milosevic \& Samuels; Olsson \& Lindqvist). Even if one admits that gnathological records and the articular appear to be reliable and consistent, at least under laboratory conditions, the exact source of error - whether it is material or human - has not been established and evaluated. Errors involved in obtaining bite records and in mounting procedures reduce the significance of the gnathological findings. Furthermore, for the aim of the present study, the manner in which the data were obtained was sufficient to enable a comparison between them (Rinchuse \& Kandasamy).

Another point to question with regard to the results of this study is the fact that the discrepancies present before the beginning of treatment were not made available. In fact these were not previously obtained because this was a transverse study. The thought that it would not be possible to reach a conclusion, since the study did not make such information available, is absolutely logical. According to Hwang \& Behrents, a longitudinal study would be the most indicated research design, in order to compare the pre- and post-treatment discrepancies in each patient. In this type of study, however, the intention of the investigation may influence the treatment and results. How can one then deduce whether the accessory in question would or would not be capable of changing this relation? This question needs to be elucidated. The factor that encouraged this research to be conducted was the fact that various authors (Shildkraut et al., 1994; Hidaka et al.; Klar et al.) have affirmed that one cannot predict the frequency, magnitude or direction of the discrepancies between $\mathrm{CR}$ and $\mathrm{CO}$, either by the Angle classification, facial type, angle ANB, mandibular plane angle, age or sex. Therefore, one presupposes that these discrepancies are similar in patients before orthodontic treatment. 
The present study presented a lower percentage of discrepancy in comparison with the findings of Clark \& Evans (1998) who analyzed 37 patients one week after they had removed the orthodontic appliance. These authors found discrepancies less than $1 \mathrm{~mm}$ in $57 \%$ of the patients in the horizontal direction, and in $68 \%$ of the patients in the vertical direction. In the transverse direction, these authors found no discrepancies in $27 \%$ of the patients. The difference in the discrepancies between the two studies may be due to the fact that the patients in the mentioned research had removed the appliance only during the previous week, which did not allow for sufficient time for adequate intercuspidation to have occurred. In the present research the patients had to have been at the contention stage for at least 3 months, in order to participate in the research. Another question could be the experience of the professionals who performed the treatment. The patients could have been treated by post-graduate students, which in fact contributes to a greater incidence of interferences (Milosevic \& Samuels).

When compared with the work of Olsson \& Lindqvist who evaluated 210 patients after orthodontic treatment, the present study also presented a higher percentage of discrepancy. It is pointed out that in the mentioned study, the patients were submitted to occlusal adjustment by selective wear every six months, until the 18th month after orthodontic treatment. In the present study, the patients were not submitted to this procedure. According to these authors, no discrepancies in the horizontal direction were found between $\mathrm{CR}$ and $\mathrm{CO}$, in 35.7 $\%$ of the patients after orthodontic treatment, whereas in the present study, this value was $16.66 \%$. As regards the incidence of lateral slide, these authors found not slide between CR and CO in $91.4 \%$ of the patients, whereas in the present study this value was $63.33 \%$.

The comparisons pointed out above with previous studies (Clark \& Evans, 1998; Olsson \& Lindqvist) are limited because the present study was the first to compare the CR-CO occlusal discrepancies between two types of orthodontic treatment. Furthermore, it was not possible to compare the data found in this study with those of other studies (Hidaka et al.; Klar et al.; Kulbersh et al.; Cordray) published because these made available only the discrepancies at condylar level.

CONCLUSION. In this study, the hypothesis that the use of sagittal Class II elastic would be capable of increasing the discrepancies between $\mathrm{CR}$ and $\mathrm{CO}$ in vertical, horizontal and transverse directions was not proved.
DE CARVALHO, É. M. G.; ESTEVES, M. R.; HORTA, M. C. R.; SILVEIRA, G. S. \& SERAIDARIAN, P. I. Influencia de los elásticos de clase II sobre la discrepancia de relación céntrica para la oclusión céntrica después del tratamiento ortodóncico. Int. J. Odontostomat., 11(4):487-493, 2017.

RESUMEN: El objetivo de este estudio fue verificar la influencia del uso de los elásticos intermaxilares Clase II en la discrepancia oclusal entre la relación céntrica (RC) y la oclusión céntrica $(\mathrm{OC})$. Un total de 30 pacientes que permanecieron en la fase de contención durante al menos tres meses se dividieron en dos grupos: G1 - 15 fueron sometidos solamente a la mecánica ortodóncica intramaxilar, y G2 - 15 habían utilizado elásticos de clase II intermaxilar. Se midieron las distancias de traslapo horizontal y vertical y la distancia o coincidencia de la línea mediana dentaria mandibular con respecto a la línea mediana maxilar en las posiciones RC y OC. Las comparaciones entre grupos se realizaron mediante la prueba de Mann-Whitney. No se encontraron diferencias estadísticamente significativas $(P>$ 0.05 ) entre $\mathrm{G} 1$ y G2. Tanto en las direcciones horizontal como vertical, estas discrepancias fueron menores o iguales a 1 $\mathrm{mm}$ en el 96,66\% de los pacientes. En el plano transversal, no hubo discrepancia en el $63,33 \%$ de los pacientes, y en un $33,33 \%$ estas discrepancias fueron iguales a $0,5 \mathrm{~mm}$. El uso de la clase II elástica no logró aumentar las discrepancias entre RC y OC.

PALABRAS CLAVE: maloclusión, ortodoncia, oclusión dental, registro de la relación maxilomandibular.

\section{REFERENCES}

Andrews, L. F. The six keys to normal occlusion. Am. J. Orthod., 62(3):296-309, 1972.

Ash, M. M. \& Ramfjord, S. Occlusion. $4^{\text {th }}$ ed. Philadelphia, W. B. Saunders Company, 1995.

Aubrey, R. R. Centric relation controversy. Am. J. Orthod. Dentofacial Orthop., 105(5):19A, 1994.

Cabrera, M. C.; Cabrera, C. A. G.; Henriques, J. F. C.; Freitas, M. R. \& Janson, G. Elásticos em Ortodontia: Comportamento e Aplicação Clínica. Rev. Dent. Press Ortodon. Ortop. Facial, 8(1):115-29, 2003.

Clark, J. R. \& Evans, R. D. Functional occlusal relationships in a group of post-orthodontic patients: preliminary findings. Eur. J. Orthod., 20(2):103-10, 1998.

Clark, J. R. \& Evans, R. D. Functional occlusion: I. A review. J. Orthod., 28(1):76-81, 2001.

Cordray, F. E. Three-dimensional analysis of models articulated in the seated condylar position from a deprogrammed asymptomatic population: a prospective study. Part 1. Am. J. Orthod. Dentofacial Orthop., 129(5):619-30, 2006.

Dawson, P. E. Functional occlusion: from TMJ to smile design. St. Louis, Mosby/Elsevier, 2006.

Ellis, P. E. \& Benson, P. E. Does articulating study casts make 
DE CARVALHO, É. M. G.; ESTEVES, M. R.; HORTA, M. C. R.; SILVEIRA, G. S. \& SERAIDARIAN, P. I. Influence of class II elastics on centric relation and centric occlusion discrepancy after orthodontic treatment. Int. J. Odontostomat., 11(4):487-493, 2017.

a difference to treatment planning? J. Orthod., 30(1):459, 2003.

Hidaka, O.; Adachi, S. \& Takada, K. The difference in condylar position between centric relation and centric occlusion in pretreatment Japanese orthodontic patients. Angle Orthod., 72(4):295-301, 2002.

Hwang, H. S. \& Behrents, R. G. The effect of orthodontic treatment on centric discrepancy. Cranio, 14(2):132-7, 1996.

Klar, N. A.; Kulbersh, R.; Freeland, T. \& Kaczynski, R. Maximum intercuspation-centric relation disharmony in 200 consecutively finished cases in a gnathologically oriented practice. Semin. Orthod., 9(2):109-16, 2003.

Kulbersh, R.; Dhutia, M.; Navarro, M. \& Kaczynski, R. Condylar distraction effects of standard edgewise therapy versus gnathologically based edgewise therapy. Semin. Orthod., 9(2):117-27, 2003.

Lucia, V. O. Remounting procedure for completion of fullmouth rehabilitation. J. Prosthet. Dent., 30(4 Pt. 2):67984, 1973.

Milosevic, A. \& Samuels, R. H. Functional occlusion after fixed appliance orthodontic treatment: a UK three-centre study. Eur. J. Orthod., 20(5):561-8, 1998.

Monnerat C, Mucha JN. Ortodontia, oclusão, estabilidade. $R$ Dental Press Ortodon. Ortop. Facial, 5:32-44, 2000.

Okesson, J. P. Management of Temporomandibular Disorders and Occlusion. 7th ed. St. Louis, Mosby/Elsevier, 2012.

Oliveira, D. D.; Oliveira, J. H. G.; Drumond, M. E. L.; Seraidarian, P. I. \& Monnerat, M. E. Critérios objetivos de avaliação clínica para finalização ideal de casos tratados ortodonticamente. Rev. Clin. Ortodon. Dent. Press, 6(5):59-68, 2007.

Olsson, M. \& Lindqvist, B. Occlusal interferences in orthodontic patients before and after treatment, and in subjects with minor orthodontic treatment need. Eur. J. Orthod., 24(6):677-87, 2002.

Rinchuse, D. J. \& Kandasamy, S. Centric relation: A historical and contemporary orthodontic perspective. J. Am. Dent. Assoc., 137(4):494-501, 2006.

Roth, R. H. Functional occlusion for the orthodontist. J. Clin. Orthod., 15(1):32-40,44-51, 1981.

Roth, R. H. Occlusion and condylar position. Am. J. Orthod. Dentofacial Orthop., 107(3):315-8, 1995.

Shildkraut, M.; Wood, D. P. \& Hunter, W. S. The CR-CO discrepancy and its effect on cephalometric measurements. Angle Orthod., 64(5):333-42, 1994.

Türp, J. C.; Greene, C. S. \& Strub, J. R. Dental occlusion: a critical reflection on past, present and future concepts. J. Oral Rehabil., 35(6):446-53, 2008.

Zhou, J. H.; Bai, D.; Jing, Y.; Ye, Y.; He, Y.; Zhang, K. \& Duan, P. J. Condylar position of post-orthodontic patients with class II malocclusion. Sichuan Da Xue Xue Bao Yi Xue Ban, 41(5):849-53, 2010.
Corresponding author:

Giordani Santos Silveira

Department of Dentistry

Pontifical Catholic University of Minas Gerais.

Rua Dom José Gaspar 500 - Prédio 45

Coração Eucarístico

ZIP 30535-610

Belo Horizonte, MG

BRAZIL

Email: giordanisilveira@hotmail.com giordanisilveira@gmail.com

Received: 02-08-2017

Accepted: 17-10-2017 